\title{
A three-phase model proposal for the evolution of scientific communication: from first print periodicals to current electronic communication system
}

\author{
Proposta de modelo trifásico para a evolução da comunicação \\ científica: dos primeiros periódicos impressos ao sistema de \\ comunicação eletrônica atual
}

Patrícia BERTIN ${ }^{1}$

\begin{abstract}
Scientific communication has undergone deep transformations, since the emergence of Internet. Aiming to provide further thought on the evolution of scientific communication, this paper features a historical overview of the scientific communication advances over the last twenty years through a three-phase model for the evolution of the electronic journal and the preprints services, and presents Brazilian contemporary panorama for scientific communication. The three-phase model presented in this work is an adaptation of that one proposed by Tenopir et al. (2003) to describe the patterns of journal use by scientists since 1990. The early evolutionary phase followed the emergence of the first digital journals and the creation of repositories in the Web for publishing preliminary versions of scientific literature on the author's initiative; by that time, most academics reproved electronic publishing initiatives. From 1996 and forward, in the consolidation phase, electronic journals were commonly identical to their print counterparts; the acceptance of the electronic format began to increase, and preprint services got underway in several disciplines. The advanced evolutionary phase started with the world discussion on open access to scientific information. The comparison of the current electronic journal with that viewed by enthusiasts in the first years of the 1990s shows that some aspects still remain to be improved in electronic formal and informal communication, towards effective dissemination of scientific information.
\end{abstract}

Keywords: scientific communication; electronic journal; e-publishing; open access; information dissemination.

RESUMO

A comunicação científica tem experimentado transformações profundas, desde a emergência da Internet. Como fo mento à questão da evolução na comunicação científica, este artigo apresenta uma perspectiva histórica dos avanços na comunicação científica ao longo dos últimos vinte anos, por meio de um modelo de três fases para a evolução do jornal eletrônico e serviços de preprints, e fornece elementos que descrevem o panorama atual para

\footnotetext{
${ }^{1}$ G erente-Adjunta de O rganização e Difusão da Informação, Embrapa Informação Tecnológica, Empresa Brasileira de Pesquisa Agropecuária - Embrapa. Parque Estação Biológica - PqEB, W3 Norte (final), 70770-901, Brasília, DF, Brasil. E-mail: < patricia@sct.embrapa.br>.

Recebido em 31/3/2007 e aceito para publicação em 5/11/2007.
} 
a comunicação científica no Brasil. 0 modelo trifásico apresentado neste trabalho é uma adaptação daquele proposto por Tenopir et al. (2003) para descrever os padrões de uso de jornais pelos cientistas desde 1990. A fase evolucionária inicial seguiu a emergência dos primeiros jornais digitais e a criação de repositórios na Web para publicação de versões preliminares de trabalhos científicos por iniciativa do autor; àquele tempo, acadêmicos tradicionais reprovavam iniciativas de publicação eletrônica. De 1996 em diante, na fase de consolidação, os jornais eletrônicos comumente consistiam em cópias idênticas de suas versões impressas; a aceitação do formato eletrônico começou a aumentar, e os serviços de preprints disseminaram- se em várias disciplinas. A fase evolucionária avançada iniciou-se com a discussão mundial sobre o acesso livre à informação científica. A comparação do jornal eletrônico corrente com aquele imaginado pelos entusiastas nos primeiros anos da década de 1990 mostra alguns aspectos que podem, ainda, ser melhorados na comunicação formal e informal, visando a efetiva disseminação da informação científica.

Palavras-chave: comunicação científica; jornal eletrônico; publicação eletrônica; acesso livre; disseminação da informação.

\section{INTRO DUCTIO N}

Social communication comprises the exchange of information between individuals by means of a common signal system, e.g., speaking, writing or through gestures. Scientific communication, specifically, is a component of social communication that has currently undergone profound transformations:

- Mikhailov defined that scientific communication is "the combined process of presentation, delivery, and receipt of scientific information in human society" (Mikhailov et al., 1984). The processes implicated in scientific communication - the basic mechanism for the existence and development of science - can be described as: the direct dialogue among scientists about research or development in which they are engaged;

- the visits to colleague's laboratories, scientific or technical exhibitions;

- the oral presentation by scientists in lecture halls;

- the exchange of letters, preprints, and off prints of publications;

- the preparation of research results and development for publication, including the choice of the form of publication (letter to the editor of a journal, manuscript for deposit, article in a journal, report, presentation, patent claim, rationalization proposal, survey, monograph, or textbook) and the place and time of publication;

- the editorial/publishing and typographic processes;
- the distribution of scientific publication;

- the library/bibliographic activity and manuscript work; and

- the scientific information activity, that comprises the collection, storage, searching, and distribution of scientific information (Mikhailov et al., 1984).

Formal scientific communication through scholarly journals exists since the $17^{\text {th }}$ century. The documentation and dissemination of concepts through scientific works of accepted genre, as extensions of the seventeenth century scientific letters, appeared in 1665, with the first two scientific periodicals - the Journal des Sçavans (Paris) and the Philosophical Transactions of the Royal Society of London -, both published byscientific societies (Meadows, 1998).

In a natural way, scientific periodicals started to assign the role of acknowledgement of discoveries' authorship and to presentinformation in a form of an indexed article (Schauder, 1994). Until nowadays, scientific periodicals continuous to be an important part of the scientific acknowledgement system (C ronin; 0 verfelt, 1995), and the assessment by experts of material submitted for publication - the peer review system - has remained as a useful quality control tool and a critical component of the editorial process and scholarly communication, adding value to the process of scientific communication through results validation.

\section{A historical perspective of scientific communication}

The last years of the $20^{\text {th }}$ century have known a reaction to the restriction of the traditional system of 
scientific communication. Many investigators and other actors have criticized the delay between submission and publication of works, which somehow reveals the inability of the traditional system to attend the increasing capacity demand for recent scientific progresses dissemination, as a result of the global expansion of research and development. The increasing specialization within all disciplines caused this exponential growth of information and brought about further expansion of new journal titles until the flood of new periodical literature began to spur the notion of 'information overload'.

By that time, the debate was still about:

- the obligation of depending on the editors for achieving diffusion of research results to the largest scale (Bachrach et al., 1998);

- the requirement of subscription or 'pay-perview';

- the strictness of the peer review system;

- the high manuscript rejection rates;

- the tendency of system to focus on the quantity of output, favor sanctioned institutions and renamed authors, suppress new ideas and endorse traditional research methods (Harnad, 1998; 2000); and

- the price of journals increases causing cancellations by libraries, which, in turn, are followed by new price increases (C ase, 2001).

The concern about developing new forms of formal and informal communication among scientists and the appearing of innovative approaches for accessing research and development results emerges from this scenery, together with the new information technologies' emergence, particularly Internet.

Since Internet presents the potential to disseminate information worldwide almost instantaneously, this newly emerged communication channel changed the way research used to be performed and the researchers' collaborate process. 0 ther Internet properties like the multimedia ambient, the interactive media, the facility of establishing cooperation despite the time and geographic distances, and its applicability for both informal and formal communication provided additional elements to the debate on new forms of scientific communication.

With this new channel of communication, new opportunities appeared for scientific communication in such a way that cooperation among scientists has changed and the barriers between formal and informal literature started to fade, resulting in a continuum of collaborative and interactive work (Borgman, 2000; Kling; McKim, 2000).

This paper features a historical overview of the scientific communication advances, and proposes a three-phase model for the evolution of the electronic journal over the last twenty years, highlighting Brazilian current situation for scientific communication. Comparing the attributes of the current electronic periodical with that seen by enthusiasts in the firstyears of the 1990s, this study points out some aspects that still can be improved in electronic journal, towards effective dissemination of scientific information.

\section{A three-phase model proposal for the re- cent evolution of scientific communication}

The evolution of scientific communication over the past twenty years essentially encompasses the development of the electronic journal, which will be described in a perspective of the three-phase model proposed by Tenopir et al. (2003) to describe the patterns of journal use by scientists since 1990, with adaptations, as explained below.

\section{The early evolutionary phase}

Lancaster meticulously documented the basis of the increase in library costs in 1978, and saw "paperless information systems" as a possible solution to the problem (Lancaster, 1978). However, the real beginning of the electronic journal (or 'e-journal') is to be found in the late 1980's.

According to some sources, the very first electronic journal was "New Horizons in Adult Education" - a refereed journal focused on current thinking and research within adult education and related fields, published two or three times each year, launched by the Syracuse University Kellogg Project from 1987 (Hugo; N ewell, 1991; Suber, 2007). Additionally, there are indications that the second electronic journal to appear was "N ewsletter on serials pricing issues", from 
the American Library Association, in 1989 (Tuttle, 1991), followed by the "Postmodern culture" (V o hns Hopkins University), the "Psycolloquy" (American Psychological Association) and the "Public-Access Computer Systems Review" (University of Houston), all launched in 1990 (Bailey J., 1992; Miran; Medeiros, 2001). In the initial phase of development, electronic journals were innovative, characterized by the absence of a printed version and distributed by e-mail, ftp or go pher.

Additionally, the early 1990's saw the creation of repositories in the web for publishing preliminary versions of gray scientific literature (preprints) on the authors' initiative (self-publishing) - the e- prints archives. The first e-print archive, ArXiv, launched in August 1991 and used among high-energy theoretical physicists at the Los Alamos National Laboratory (G insparg, 1994), is still online and currently provides access to 406,884 e-prints in the fields of Physics, Mathematics, N on-linear Science, Computer Science and $\mathrm{Q}$ uantitative Biology.

However, the first studies on usage and acceptance of electronic journals show that most academics viewed electronic publishing as experimental, atbest According to writings of Kling and Covi, a scholar who was facing a choice between publishing in a print journal and publishing in an electronic journal faced a choice between legitimate (butperhaps slow) publication, and more rapid publication in electronic journals that were viewed as of lesser quality or even not serious journals (Kling; Covi, 1995). The widespread notion was that print journals were better able to assure appropriate readership than electronic journals, with few exceptions (Kling; Covi, 1995).

In response to the first publishing experiments, Ann 0 kerson wrote a paper discussing several critical questions about the electronic journal and detailing possible directions that could be taken (O kerson, 1991).

In the paper, she described two interesting visions of electronic journals. The first vision delineates the subsequent evolutionary phase with exactness: in the majority of cases, electronic journals would mimic the current paper journal format, which means that the refereed content found in print journal would be replicated in the online site. The second vision suggests dramatic change in the whole process of scholarly communication, thatwould become instant, global, and interactive (Harnad, 1990). This visionaries' electronic journal would open windows onto ideas attached as supplementary files, footnotes, sounds, and visual matters - writing would not be confined to any place or time or group whilst paper distribution would take place secondarily.

\section{The consolidation phase of the electronic channel for scientific formal and informal communication}

The book "ScholarlyJ ournals at the C rossroads: A Subversive Proposal for Electronic Publishing", edited by Ann Shumelda 0 kerson and James J. O 'Donnell, launched in 1995, makes publishing history (O kerson; 0 'Donnell, 1995). It was based on an e-mail discussion held in the summer and fall of 1994 about scientific journals and their future, and suggested a radically decentralized scholarly publishing model, in which scholars self-publish their works, which then may or may not be peer-reviewed (Brent, 1995; 0 kerson and 0 'Donnell, 1995).

In the consolidation phase, through collaboration with scholarly and professional societies, preprint services got underway in several disciplines, although still in the early stages of planning.

From 1996 and forward, possibly as a response to the recent debate on the future of scientific communication, headed by enthusiasts like Paul G insparg, Steven Harnad, Andrew 0 dlyzko, and Ann 0 kerson, many print journals started to produce electronic editions of their content. During this second stage of the evolution of scientific communication, the majority of electronic journals were close copies of their printed journals. Articles on paper were scanned and made available as bitmap files after the publication of the original articles.

At that point in time, scientists started to recognize electronic journals as alternatives to print journals (Harter, 1998; Tomney; Burton, 1998). In spite of that, peer group pressures (G omes; Meadows, 1998), technical barriers and lack of knowledge (Bishop, 1998) disturbed the acceptance of electronic journals in the evolving phase.

From 1991 to 2000, there has been an incredible increase on the number of electronic journals (Table 1). 
In that course of time, peer-reviewed electronic journals increased from $26 \%$ to $43 \%$ of total, which strengthens the notion that peer review was still considered the best available approach for quality assurance in scientific communication. In other words, the number of peer- reviewed electronic joumals increased well over 550 times between 1991 and 2000. Although peer review has declared imperfections, some specialists admit that there is no viable alternative, whether on paper or on the electronic airwaves (Harnad, 1986, 1998).

Table 1. The growth of electronic publishing, peer review and charge requisition from 1991 to 2000.

\begin{tabular}{lccccccccc}
\hline Item considered & \multicolumn{7}{c}{ Number per year } \\
\cline { 2 - 9 } & 1991 & 1992 & 1993 & 1994 & 1995 & 1996 & 1997 & 2000 \\
\hline Total number of electronic journals and magazines & 27 & 36 & 45 & 181 & 306 & 1,093 & 2,459 & 5,451 \\
Peer-reviewed electronic journals & 7 & 15 & 29 & 73 & 139 & 417 & 1,049 & 3,900 \\
Electronic journals and magazines that charge for & 2 & 2 & 6 & 29 & 72 & 168 & 912 & $-(1)$ \\
access & & & & & & & & \\
\hline
\end{tabular}

Data obtained from the Directory of Electronic Journals, Newsletters and Academic Discussion Lists and the Directory of Scholarly Electronic J ournals and Academic Discussion Lists. ${ }^{(1)}$ M issing value.

Digitization was definitely the major responsible for the dramatic rise in number of scholarly electronic journals from 1996 to 2000. Still in 1999, Wells found 387 'free' electronic journals, defined as "independent, electronic scholarly journals, that is, those that are available through the Internet, usually the World Wide Web, free of charge to the reader, and publish academic articles, usually peer reviewed" (Wells, 2007).

Coming back to the data presented in Table 1 , it can be observed that the number of electronic journals/ magazines that charge a fee for access rose from $7 \%$ to $37 \%$, in the first seven years. It clearly denotes that, if this number had continued growing at that rate and if a revolutionary movementhad notoccurred, around 2010 we would undergo an overload of electronic journals that no library would attend. Similarly to the 'library crisis', the payment for electronic access would be a great-unresolved question and a new impasse in scholarly communication would be generated.

In Brazil, the first electronic scientific journal was The J ournal of Venomous Animals and Toxins including Tropical Diseases, launched in 1995. Published by the Center of Studies on Venomous Animals of the São Paulo State University (Unesp), its initial fascicles were distributed in diskettes (Souza, 2002, p.41). In parallel, the N ucleus of Biomedical Informatics (N IB) of the State University of C ampinas (Unicamp) initiated a pioneer project of electronic scientific publication, with the development of the 'Virtual Hospital', a resource of medical information in the Internet. The Virtual Hospital was followed by the foundation of the e*pub - the $G$ roup of Electronic Publications in Medicine and Biology -, which was responsible for the development of electronic journals like the $O$ nline Journal of Plastic and Reconstructive Surgery, the firstpurelyelectronic Brazilian scientific periodic, and the Journal of the Cardiology Society of the São Paulo State.

A more recent and significant national initiative for the improvement of the scientific research communication was the Scientific Electronic Library O nline (SCIELO), a program that celebrates ten years of existence. The SciELO was implemented in the beginning of 1997 as a cooperative project between the LatinAmerican and $\mathrm{C}$ aribbean $\mathrm{C}$ enter on Health Sciences Information (BIREM E/PAHO / WHO ) and the State of São Paulo Research Foundation (FAPESP). The first year was dedicated to developing a methodology to publish fulltext journals on the Web, and the editors of ten Brazilian journals that comprised the first SciELO Brazil collection participated actively. The SciELO Brazil portal started operating publicly in 1998. As from 2002, the project has also been supported by the National Council for Scientific and Technological Development (CN Pq) of Brazil. Promoted by the BIREME and supported by the CO NICYT C hile, the SciELO progressively developed as a network of open access journal collections, extending its activities to the Caribbean countries, Portugal and Spain, using the same methodology to publish online journals and provide links in the internet, as well as to follow up the performance of individual articles, journals and collections. 


\section{The advanced evolutionary phase}

In the advanced phase of the evolution of scientific communication, the number of available titles increased in the Internet, and the integration of this medium into the scientist's information habits turned out to be significant. Starting in 2000 , this stage was characterized by the several initiatives taken in support of the open access to scientific information, at the same time the first ' $O$ pen Access' journals appear.

Committing to memory the concept of ' $O$ pen Access', it was first properly defined in 2001, ata meeting that took place in Budapest, promoted by the 0 pen Society Institute, a group of open access activists (even though at the time they didn't all use the term 'open access' yet). 0 ut of that meeting came the so-called 'Budapest 0 pen Access Initiative' (BO Al) and open access was defined in that initiative as follows (Budapest 0 pen Access Initiative, 2002):

\footnotetext{
By 'open access' to this literature [primarily peerreviewed journal articles, as mentioned earlier in the Initiative], we mean its free availability on the public internet, permitting any users to read, download, copy, distribute, print, search, or link to the full texts of these articles, crawl them for indexing, pass them as data to software, or use them for any other lawful purpose, without financial, legal, or technical barriers other than those inseparable from gaining access to the internet itself. The only constraint on reproduction and distribution, and the only role for copyright in this domain, should be to give authors control over the integrity of their work and the right to be properly acknowledged and cited.
}

From BO Al, two basic strategies were established in order to make research articles freely available on the Internet: the self-archiving, which means the deposit of authors' refereed journal articles in open electronic archives; and the instigation of a new generation of journals committed do open access, and the assistance to existing journals that elect to make the transition to open access.

In April 2003, fifteen months later the BO Al, the 'Bethesda Statement' was proclaimed from a one-day meeting of scientists, funding agencies, librarians, scientific societies and publishers. The essence of open access' definition in the Bethesda Statement remained the same, but it focused more on actual legal and practical consequences (0 pen Society Institute, 2005).

Yet in 2003, the Max Planck Society in G ermany, convened a meeting on " $O$ pen Access to Knowledge in the Sciences and Humanities" and produced the "Berlin Declaration on 0 pen Access', resulting the inclusion of the humanities in the discussion. This declaration considers that open access is real open access if:

- the article is universally and freely accessible, at no cost to the reader, via the Internet or otherwise, without embargo;

- the author or copyright owner irrevocably grants to any third party, in advance and in perpetuity, the right to use, copy, or disseminate the article, provided that correct citation details are given; and

- the article is deposited, immediately, in full and in a suitable electronic form, in at least one widely and internationally recognized open access repository committed to open access and long-term preservation for posterity (Berlin Declaration on 0 pen Access to Knowledge in the Sciences and Humanities, 2003).

After these innovative initiatives, many other movements around the world occurred in support of 0 pen Access. In January 15, 2004, on the campus of the Pontificia Universidad Catolica de Valparaíso (PUCV) in Valparaiso, Chile, a workshop was held on the possibilities of electronic publication, in which 120 delegates from 15 countries participated, which resulted in the drafting of the Valparaiso Declaration for Improved Scientific Communication in the Electronic Medium. Few months later, in Brazil, participants at the $2^{\text {nd }}$ International Digital Libraries Symposium in Campinas, on May 21, 2004, issued a statement in support of open access (Suber, 2007). The next official documents supporting the open access initiative in Brazil were the "Declaration of Salvador - Commitment to Equity" and the "Salvador Declaration on 0 pen Access: the developing world perspective", which were produced during the International Seminar on 0 pen Access for Developing Countries (Salvador Declaration on 0 pen Access: the developing world perspective, 2005). In December 2005, as an initiative of researchers, librarians and São Paulo's citizens signed up a declaration 
supporting open access to scientific information (Acesso..., 2005). In 2006, participants in the Convention on Biological Diversity in Curitiba, March 31 , adopted a statement endorsing open access for biodiversity data. Little time after, Florianópolis declared support to open access, during a symposium of the National Asso ciation of Research and Postgraduate in Psychology (IBICT, 2006) whereas attendees of the 2006 iC ommons iSummit, in Rio de Janeiro, released the Rio Declaration on 0 pen Access (Suber, 2007).

Atpresent, the Directory of 0 pen Access J ournals, DO AJ - a systematic service that covers free, full text, quality controlled scientific and scholarly journals includes at the present 2602 journals (at the time of writing this paper), covering several subjects and languages (Directory of 0 pen Access) ournals - DO AJ, 2007). A survey on this directory reveals 203 Brazilian journals that currently provide open access to scientific information. Interestingly, from these 203 journals, 178 belong to the SciELO collection.

Equally significant, the Registry of 0 pen Access Repositories - RO AR (2007), a service that promotes open access to the research literature pre- and postpeer review through author self-archiving, registers a number of 853 e-print archives: the majority content is Research Institutional or Departmental (437 repositories). With 50 repositories registered in RO AR, Brazil is among the nations that report the greatest number of repositories, occupying the $4^{\text {th }}$ position of the ranking, just after the United States, the United Kingdom and Germany 210, 93 and 78 repositories, respectively. From the Brazilian registered e-prints, only five are Research Institutional or Departmental archives. This data advertises that Brazilian scientific community has still not assimilated institutional reposito ries.

Another electronic service that provides a list of open access repositories around the world that wholly embraces the conceptof open access to full textresources, excluding electronic journals - the Directory of 0 pen Access Repositories - 0 penDO AR (2006) - currently registers 852 repositories, and places Brazil in the $7^{\text {th }}$ position, with 25 repositories reported, after the United States (250), G ermany (110), the United Kingdom (94), Australia (51), the Netherlands (44), France (31), Sweden (30), and Canada (29). The analysis of data obtained from both RO AR and 0 penDO AR shows that half of the Brazilian digital reposito ries really correspond to electronic journals archives.

\section{Current view for scientific communication}

Plenty of positive aspects associated to electronic journals, particularly those adopting 0 pen Access policies, are acknowledged worldwide:

- Electronic publication can maximize the research results' impact thus promoting a change of roles in publication system and giving researchers the deserved acknowledgment. Regarding the impact of electronic journals, Lawrence registered that online articles are cited 4.5 times more often than offline articles (Lawrence, 2001), when considering articles within each year, and averaging across all years from 1990 to 2000.

- Information can be much more up-to-date and easy to find in Internet than could be achieved with paper.

- Foment institutions are interested in changing the view about scientific publication, in a way thatfinanced researches could be as accessible as possible. 0 pen Access could, this way, maximize access to scientific research, increase research's progress, impact, productivity and rewards. 0 ne of the core advantages of digital format, for the foment institutions, is its capacity for searching, which results in reducing lost time with duplicated efforts worldwide.

- With the ease of communication provided by electronic mails, a much greater feedback is achieved through the Web, favoring interactivity.

- Links are considered a mainstay of the hypertext format. Papers can link to those they have cited and, more interestingly, articles can be linked to those that cite them.

- Virtual reality, animation, interactive mathematical charts, and supporting data can present a deeper look into the results, adding value to digital scientific communication. That means that online journal can publish data, programs, animations, and multimedia components that no print journal can publish. 
The proliferation of electronic journals continues to be phenomenal. The latestedition of the LISU Annual Library Statistics of 2006 reports that, of the more than 188,500 serials listed, 45,000 are available exclusively online or in addition to a paper counterpart (C reaser; Maynard; White, 2006).

By the way, there has been an increase this year in the number of periodicals available in CD-ROM, after a slight fall three years ago (C reaser; Maynard; White, 2006). $>$ From those 45,000 periodicals, almost 7,000 are now published in CD-RO M, what denotes a search for alternative systems of scientific communication.

Based on a search of the 2002 online edition of Ulrich's International Periodicals Directory (2007), Tenopir et al. (2002) detected approximately 15,000 active, peer-reviewed titles, of which 12,000 were available electronically, and the majority of the electronic journals were still replicas of traditional print journals (Tenopir et al., 2003). Considering that the number of serial titles listed by Ulrich for the year considered was of 164,000 , it is easy to find that $9.15 \%$ of the world' serial titles used peer review by that time.

Consistently with that reasoning, $80 \%$ of the peerreviewed titles were then electronically available, which means that the electronic media has been legitimated for scientific communication and many electronic journals have achieved credibility.

The current consensus seems to be that, although there are problems with peer review, it is unlikely to be abandoned, butmay be opened up. Some works propose a reform to peer review in order to encourage innovation without sacrificing quality control, particularly by developing new ways to undertake it online (Till, 2000). Publicly identified reviewers, readers and editors should post comments and authors would prepare a final version and submit it for publication in the archives of the desired journal.

However, much of the peer-reviewed literature is still unavailable through open access publishing. For instance, the number of journals listed in DO AJ in 2005 constituted only $7 \%$ of the world's peer-reviewed titles listed by U Irich (Kirsop; Chan, 2005).

Calling attention to the Library and Information Science and through a survey of the electronic journals presently indexed at the DO AJ, it can be extracted that, from the 764 titles indexed, 71 are issues related to this field of knowledge. An analysis of the course of indexing of these journals, in the period of 1991 to 2006, reveals two major peaks (Table 2 ).

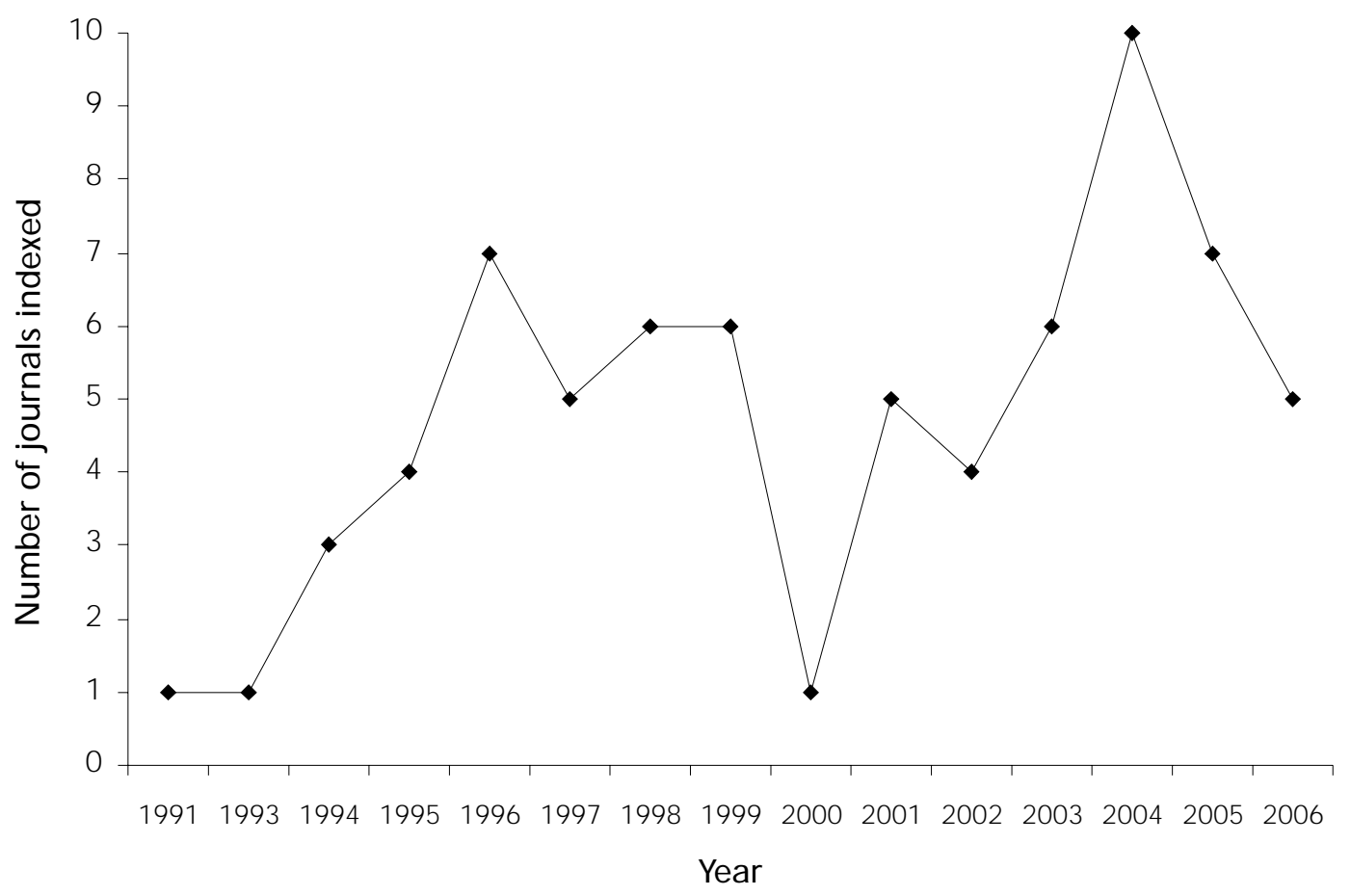

Table 2. Indexing of J ournals on Library and Information Science in the Directory of O pen Access Journals ( $D O A J$ ), from 1991 to 2006. 
The boom of electronic journals on Library and Information Science observed in 1996 could be a repercussion of the discussion directed by the core group of enthusiasts on e-publishing (e.g. Paul G insparg, Steven Harnad, Andrew 0 dlyzko, and Ann 0 kerson), well known for their provocative writings.

The next prominent peak of electronic journals on Library and Information Science indexed in DO AJ, distinguishable in the year 2004, can be related to the important initiatives on 0 pen Access that took place in 2003, starting with the BO Al, and followed by the Bethesda Statement on 0 pen Access Publishing and the Berlin Declaration on 0 pen Access to Knowledge in the Sciences and Humanities.

With respect to the adoption of the electronic media for scientific communication, a recent survey shows a significantly high acceptance of electronic journals and repositories, and an unwillingness to return to print versions only (Rusch-Feja; Siebeky, 1999). According to Swan and Brown (2005), a vast majority of authors $(69 \%$, among those who have never published in open access journals), if required to deposit copies of their published articles in one or more repositories, declared that would do so willingly (Swan; Brown, 2005). This data reinforce the acceptance of the electronic repositories by scientific community.

Moreover, a great number of journals over $90 \%$ - give permission for authors to self archive their papers (Sherpa, 2006). However, self-archives still do not include many audio or video files, which represent less than $10 \%$ of digital objects available in the electronic repositories (Swan; Brown, 2005).

Although Internet has modified traditional information organization on a scale never seen before and instigated new scientific communication models, some questions remain not solved. Has Internet really revolutionized access to scientific communication? Have we achieved the place visionaries of the electronic journal described? With regard to scientific communication, are today's matters different from those sixteen years ago?

Visionaries of electronic journals dreamed that scientific ideas would be sprouted precisely when it is ready, criticized via the Internet, and put out immediately for open peer commentary or wide examination.

Unfortunately, electronic scientific communication has not reached that place. $N$ ot yet. The multimedia potential of Internethas been poorly used to advantage; the electronic journal frequently uses a conventional peer review system; the great majority of electronic journals still mimiks their print versions in design, conception, content delivery; and there also remains a significant gap between a manuscript submission and publication.

From the scenario Ann 0 kerson described for the evolution of scholarly journals (0 kerson, 1991), most predictions have become true in this advanced phase of the evolution of scientific communication: computer equipment and user-sophistication are currently pervasive, but notubiquitous; electronic and paper versions are available for serious academic journals; subscription model decreases whereas license and single-article models expand; some journals transfer their electronic versions to commercial owners, butaccess costs are low; secondary services re-think roles at the same time as other indexing services strengthens; new niches are created; publishers without electronic delivery shrink; and Copyright Law is being revised. Just one of 0 kerson's predictions seems not to correspond to reality in the early years of the $20^{\text {th }}$ century: the occurrence of stratification of richer and poorer users, universities, and nations.

Although there was a hesitation that with information converted to digital formats, scholars in developing countries would be disadvantaged, some thinkers argue that electronic journals would be a tool for further breaking down the barriers to democratic research, in view of the fact that it is still cheaper for these researchers to get one computer with Internet access than to subscribe to many journals ( $G$ insparg, 1996; Neal, 1997).

0 pen access or not, the currentelectronic journal has still to surpass some barriers, like:

- the connectivity barriers: billions of people do not have access to the digital technology, and millions of serious scholars are offline;

- the censorship barriers: as a matter of fact, many schools, employers, and governments want to limit what you can see;

- the language barriers: most online literature is in just one language, a good number in English, and machine translation is very weak;

- the handicap access barriers (most sites are not accessible to handicapped users); and

- Web sites can change their URLs or disappear altogether, in such a way that information could be lost. 


\section{CONCLUSIONS}

Information produced in the context of research and development constitutes a public good, since it most frequently counts on public financial resources: consequently, access must by guaranteed to all who need it. Therefore, open access electronic journals, together with institutional and thematic digital repositories, will continue strong. Electronic repositories do not substitute scientific periodicals' role, but complement them, taking advantage of the Internet benefits and promoting rapid diffusion of research results.

of course, formal and informal systems of scholarly communication have to transcend several barriers. Researchers from some disciplines still have notaccepted electronic channel as a legitimate means for scientific communication, and only when all those obstacles are overcome, the electronic journal will reach the place visionaries described for scientific communication in the electronic age.

Rather than just recreating a print journal in exact format, it is expected from editors thatelectronic journals shall innovate with the use of multimedia (e.g. moving images and sound), enrich the communications format (e.g. through inclusion of embedded software, datasets, etc.), use new navigational models (e.g. incorporating hyperlinks), increase user involvement and interaction, and develop new distribution formats (e.g. continuous addition of articles instead of serialization in volumes and issues).

The scientific communication advances all over the world during the last twenty years can be analyzed through the three-phase model perspective presented by Tenopir et al. (2003) with adjusting. Formal systems of scholarly communication, in developing countries like Brazil or in the most prosperous nations still have to transcend several barriers until the electronic journal and eprints services reach the place visionaries described for scientific communication in the electronic age.

\section{REFEREN CES}

ACESSO ABERTO BRASIL. Declaração de apoio ao acesso aberto à literatura científica: "Carta de São Paulo". Disponível em: < http://www.acessoaberto.org/> . Acesso em: 31 mar. 2007.

BACHRACH, S., et al. Intellectual property: who should own scientific papers? Science, v.281, n.5382, p.1459-1460, 1998.

BAILEY J r., C.W. N etwork-based electronic serials. Information Technology and Libraries, v.11, n.1, p.29-35, 1992.

BERLIN DECLARATIO N O N O PEN ACCESS TO KN O WLEDG E IN THE SCIENCES AND HUMANITIES. 2003. Disponível em: < http://oa.mpg.de/openaccess-berlin/berlin_declaration.pdf> . Acesso em: 15 mar. 2007.

BISHOP, A.P. Measuring access, use, and success in digital libraries. The Journal of Electronic Publishing, v.4, n.2, 1998. Disponível em: < http://www.press.umich.edu/jep/04-02/ bishop.html> . Acesso em: 20 mar. 2007.

BO RG MAN, C. Digital libraries and the continuum of scholarly communication. Journal of Documentation, v.56, n.4, p.412$430,2000$.

BRENT, D. Stevan Harnad's 'Subversive proposal': kick-starting electronic scholarship: a summary and analysis. The Information Society, v.11, n.4, p.261-273, 1995.
BUDAPEST O PEN ACCESS IN ITIATIVE. 2002. Disponível em: < http://www.soros.org/openaccess> . Acesso em: 20 mar. 2007.

CASE, M.M. Scholarly communication: a system in crisis. Pittsburgh Conference 2001.

CREASER, C.; MAYNARD, S.; WHITE, S. LISU Annual Library Statistics 2006. Loughborough: Loughborough University. 211p. 2006. Disponível em: < http://www.lboro.ac.uk/departments/ls/ lisu/downloads/als06.pdf> . Acesso em: 30 mar. 2007.

CRO NIN, B.; O VERFELT, K. Electronic joumals and tenure. Journal of the American So ciety for Information Science, v.46, n.9, p.700$703,1995$.

DIRECTO RY O F O PEN ACCESS JO URNALS (DO AJ). 2007. Disponível em: < http://www.doaj.org> . Acesso em: 29 mar. 2007.

DIRECTO RY O F O PEN ACCESS REPO SITO RIES (O penDO AR). 2006. University of Nottingham, UK. Disponível em: < http:// www.opendoar.org > . Acesso em: 30 mar. 2007.

GINSPARG, P.H. @ xxx.lanl.gov: first steps toward electronic research communication. Los Alamos Science, v.22, p.156-165, 1994. Disponível em: < http:// www.fas.org/sgp/othergov/doe/ lanl/pubs/00285556.pdf> . Acesso em: 30 mar. 2007. 
G INSPARG, P.H. Winners and losers in the global research village. In: the JOINT ICSU Press/UNESCO Expert Conference on Electronic Publishing in Science. Paris: Unesco, 1996. Disponível em: < http:// www. library.uiuc.edu/icsu/ginsparg. htm> . Acesso em: 15 mar. 2007.

GO MES, S.; MEADO WS, J. Perceptions of electronic journals in British Universities. Journal of Scholarly Publishing, v.29, n.3, p.174181, 1998. Disponível em: < http:// www.utpjoumals. com/product/ jsp/293/293_gomes.html>. Acesso em: 30 mar. 2007.

HARN AD, S. The invisible hand of peer review. Exploit Interative, v.5, 2000. Disponível em: < http://www. exploit-lib.org/issue5/peerreview> . Acesso em: 20 mar. 2007.

HARNAD, S. Learned inquiry and the net: the role of peer review, peer commentary and co pyright. Learned Publishing, v.11, n.4, p.283-292, 1998.

HARN AD, S. Policing the paper chase. N ature, v.322, p.24-25, 1986.

HARNAD, S. Scholarly skywriting and the prepublication continuum of scientific inquiry. Psychological Science, v.1, p.342344, 1990. Disponível em: < http://www.ecs.soton.ac.uk/ $\sim$ hamad/Papers/Harnad/hamad90.skywriting.html> . Acesso em: 30 mar. 2007

HARTER, S. Scholarly communication and electronic journals: an impact study. Journal of the American Society for Information Science, v.49, n.6, p.507-516, 1998.

HUG 0 , J.; NEWELL, L. New horizons in adult education: the first five years (1987-1991). The Public-Access Computer Systems Review, v.2, n.1, p.77-90, 1991.

INSTITUTO BRASILEIRO DE INFO RMAÇÃO EM CIÊNCIA E TECN O LO G IA (IBICT). Declaração de Florianópolis. 2006. Disponível em: < http://www.ibict.br/noticia. php?id=263>. Acesso em: 15 mar. 2007

KIRSO P, B.; CHAN, L. Transforming access to research literature for developing countries. Serials Review, v.31, n.4, p.246-255, 2005. Disponível em: <https://tspace.library.utoronto.ca/ bitstream/1807/4416/1/Kirsop_Chan_SerialsReview.pdf> . Acesso em: 20 mar. 2007.

KLING , R.; CO VI, L. Electronic journals and legitimate media in the systems of scholarly communication. The Information Society, v.11, n.4, p.261-271, 1995.

KLIN G, R.; M CKIM, G . N ot just a matter of time: field differences in the shaping of electronic media in supporting scientific communication. Journal of the American Society for Information Science, v.51, n.14, p.1306-1320, 2000.

LANCASTER, F.W. Toward paperless information systems. 0 rlando: Academic, 1978. 179p.

LAWREN CE, S. 0 nline or invisible? Nature, v.411, n.6837, p.521, 2001.

MEADOWS, A.J. Communicating research. London: Academic,1998.226p.
MIKHAILO V, A.I.; CHERNYI, A.I.; GILIAREVSKII, R. Scientific communication and informatics. Arllington: Information Resources,1984. 402p.

MIRAN , J.; MEDEIRO S, N. G lory days: managing scientific journals in a liberal arts college. Issues in Science and Technology Librarianship, v.31, p.7664, 2001. Disponível em: <http:// www.istl.org/01-summer/article3.html>. Acesso em: 30 mar. 2007.

NEAL, J.G. The use of electronic scholarly journals: models of analysis drawn from the project M use experience at J ohns Hopkins University. 1997. Disponível em: < http:// eric.ed.gov/ERIC Docs/ data/ericdocs2/content_storage_01/0000000b/80/23/cb/ 85. pdf >. Acesso em: 5 mar. 2007.

O KERSO N, A. The electronic journal: what, whence, and when? The Public-Access Computer Systems Review, v.2, n. 1, p.5-24, 1991. Disponível em: < http:// www. library.yale.edu/ okerson/ pacs.html>. Acesso em: 10 mar. 2007.

O KERSO N, A.S.; O 'DO N NELL, J.J. Scholarly journals at the crossroads: a subversive proposal for electronic publishing. Washington: 0 ffice of Scientific \& Academic Publishing Association of Research Libraries. 1995. 202p. Disponível em: < http:// www.arl.org/bm doc/subversive.pdf> . Acesso em: 28 mar. 2007.

O PEN SO CIETY IN STITUTE. O pen Access Publishing And Scholarly Societies: a G uide. 2005. Disponível em: < http:// www.soros.org/ openaccess/pdf/open_access_publishing_and_scholarly_ societies.pdf>. Acesso em: 10 mar. 2007.

REG ISTRY O F O PEN ACCESS REPO SITO RIES (RO AR). 2007. Disponível em: < http://roar.eprints.org > . Acesso em: 15 mar. 2007.

RUSCH-FEJA, D.; SIEBEKY, U. Evaluation of usage and acceptance of electronic journals: results of an electronic survey of MaxPlanck Society researchers including usage statistics from Elsevier, Springer and Academic Press (Full Report). D-Lib Magazine, v.5, n.10, 1999. Disponível em: < http://www.dlib.org/dlib/october99/ rusch-feja/10 rusch-feja-full-report.html> . Acesso em: 10 mar. 2007.

SALVADO RDEC LARATIO N O N O PEN ACCESS: the developing world perspective. 2005. Disponível em: < http:// www.icml9.org/ public/documents/pdf/en/Dcl-Salvador-O penAccess-en. pdf> Acesso em: 10 mar. 2007.

SCHAUDER, D. Electronic publishing of professional articles: attitudes of academics and implications for the scholarly communication industry. Journal of the American Society for Information Science, v.45, n.2, p.73-100, 1994.

SHERPA. Publisher copyright policies and self-archiving. 2006. Disponível em: < http://www.sherpa.ac.uk/romeo.php>. Acesso em: 28 mar. 2007

SO UZA, M.F.S. Periódicos científicos eletrônicos: apresentação de modelo para análise de estrutura. 2002. Dissertação (M estrado em Ciência da Informação) - Programa de Pós-G raduação em Ciência da Informação, Faculdade de Filosofia e Ciências da Universidade Estadual Paulista - Campus de M arília, 2002.

SUBER, P. Timeline of the 0 pen Access M ovement. 2005. Disponível em: < http://www.earlham.edu/ peters/ fos/timeline.htm> . Acesso em: 18 mar. 2007. 
SWAN, A.; BRO WN, S. O pen access self-archiving: an author study. Cornwall: Key Perspectives Limited. 104p. 2005. Disponível em: < http://eprints.ecs.soton.ac.uk/10999/01/jisc2.pdf>. Acesso em: 18 mar. 2007.

TEN O PIR, C., et al. Patterns of J ournal U se by Scientists through Three Evolutionary Phases. D Lib M agazine, v.9, n.5, 2003. Disponível em: < http://www.dlib.org/dlib/may03/king/ 05king.html> . Acesso em: 20 mar. 2007.

TILL, J.E. Peer review in a post-eprints world: a proposal. Journal of Medical InternetResearch, v.2, n.3, p.e14, 2000. Disponível em: < http://clinmed. netprints. org/cgi/content/ full/2000010010>. Acesso em: 25 mar. 2007.
TO MNEY, H.; BURTO N, P.F. Electronic journals: a study of usage and attitudes among academics. Jo urnal of Information Science, v.24, n.6, p.419-429, 1998.

TUTTLE, M. The Newsletter on serials pricing issues. The PublicAccess Computer Systems Review, v.2, n.1, p.111-127, 1991.

ULRICH'S PERIO DIC AL DIREC TO RY. Disponível em: < http:// ulrichsweb.com/ulrichsweb>. Acesso em: 20 mar. 2007.

WEUS, A. Exploring the development of the independent, electronic, scholarly journal. Sheffield: University of Sheffield/Department of Information Studies, MsC Dissertation in Information Management). Disponível em: < http://panizzi.shef.ac.uk/elecdiss/edl0001/ index.html>. Acesso em: 28 mar. 2007. 